\title{
Milyen imázst közvetítenek a magyar felsőoktatási intézmények honlapjai?
}

\section{What image is conveyed by the webpages of hungarian higher education institutions?}

\author{
M. KISS ${ }^{1}$, A. I. Kun ${ }^{2}$ \\ ${ }^{1}$ Debreceni Egyetem, Gazdaságtudományi Kar, Marketing Tanszék, kiss.marietta@econ.unideb.hu \\ ${ }^{2}$ Debreceni Egyetem, Gazdaságtudományi Kar, Emberi Erőforrás Menedzsment Tanszék, \\ kun.andras.istvan@econ.unideb.hu
}

Absztrakt. Jelen dolgozatban a felsőoktatási online marketing magyarországi gyakorlatát elemezzük feltáró jelleggel. Kutatásunkban a Magyarországon müködő államilag elismert felsőoktatási intézmények teljes körének honlapjait néhány kiválasztott, a közönség felé mutatott imázs nyitottságát mérő mutató alapján vizsgáljuk. E szempontok szerint összevetjük az állami intézményeket a nem állami (ezen belül az egyházi) fenntartásúakkal, illetve az egyetemi besorolással rendelkezőket a föiskolákkal (mind a 2000 elötti, mind az aktuális státuszok szerint). Legföbb megállapításunk, hogy a honlapok statisztikailag alátámaszthatóan közvetítenek valamely intézmény-csoportra jellemző imázst. Vannak ugyanis olyan jelzések, amelyek differenciálnak állami és nem állami intézmények, egyetemek és föiskolák között. Ezek közül mi a következőket azonosítottuk: a föoldalon közölt képek száma, slider jelenléte, a honlap akadálymentesített és idegen nyelvü elérhetösége, illetve a feltüntetett közösségimédia-elérhetőségek. Az állami intézmények, illetve az egyetemek minden vizsgált dimenzióban nyitottabb imázst közvetítettek honlapjukon.

Abstract. This exploratory study analyses the online higher education marketing practice in Hungary. It examines the homepages of all of the state accredited higher education institutions in Hungary. The selected dimensions of the examination are to measure different aspects of openness expressed by the image published on the homepages to their audience. State vs. non-state financed (and as a sub-category of the latter: church financed) institutions are compared along these dimensions, as well as universities vs. colleges (according to their status both before 2000 and present). The main finding of the research is that there is a statistically significant evidence that the homepages expressed different images for the analysed institution groups. Differentiating signals between state financed institutions vs. non-state financed institutions, as well as between universities vs. colleges were identified: the number of pictures published on the main page, the presence of sliders, the accessibility of the website to people with visual impairment and to non-Hungarian speakers, and the access to social media. State institutions and universities were found to publish a more open image via their homepages than the non-state financed institutions and the colleges. 


\section{Bevezetés}

Ma már nem csak a vállalatok, hanem a felsőoktatási intézmények is éles versenynek vannak kitéve, ráadásul a globalizáció következtében a versenytársak köre nem korlátozódik az intézmény régiójára, országára, hanem számolni kell a külföldi intézmények versenyével is [1]. Ezért az egyetemek helytállásához hozzájárulhat a profitorientált szférában már bevált marketingeszközök alkalmazása. Ezen eszközhalmaz egy szeletét képezik az online marketing eszközei, melyek egyre nagyobb szerepet töltenek be a felsőoktatás elsődleges célcsoportját alkotó generációk fogyasztói magatartásának befolyásolásában [2]. Nem lehet tehát szó nélkül elmenni az online marketingkommunikációs eszközök mellett a felsőoktatási intézmények jelenlegi és leendő hallgatóinak megismerése, igényeik felmérése, valamint ezen igényeknek megfelelő ajánlatok létrehozása és kommunikálása terén. Jelen tanulmány a kínálati oldal - a magyarországi felsőoktatási intézmények - honlapjainak vizsgálatával kíván hozzájárulni a témakör megismeréséhez.

Kutatásunk jelentős mértékben feltáró jellegű. A vizsgált témakör továbbiakban részletezésre kerülő újszerűsége, alacsony kutatottsága miatt csak átfogó kutatási kérdésekkel rendelkezhet. Ezeket a hagyományostól eltérő módon nem itt, hanem az elméleti háttér bemutatása után, az Adatok és módszer fejezetben fogalmazzuk meg. E változtatásra éppen az újszerűség miatt van szükség: először a szakirodalomra támaszkodva magát a témakört kell megismertetnünk az olvasóval.

\section{Elméleti háttér}

\section{1. Éleződő verseny a felsőoktatásban}

Az utóbbi évtizedek jelentős változásokat hoztak a felsőoktatási piacokon. Világszerte megfigyelhető a felsőoktatás deregulációja - még ha néhány esetben ezzel ellentétes folyamatok is megfigyelhetőek rövid távon - és ennek hatására piacosodása, melynek következtében a felsőoktatási intézmények egyre élesedő versenynek vannak kitéve, mind hazai, mind pedig külföldi versenytársak által [1], [3], [4]. A magyar felsőoktatási szektor állami intézményei nagyjából azonos feltételek mentén versenyeznek mind a hallgatók megszerzéséért, mind a képzés, a diploma munkáltatói elismertetéséért, fokozta viszont a versenyt az államilag engedélyezett magán intézmények megjelenése [5]. Bár az egyetemi hallgatók országok közti vándorlásának történelme évszázadokra tekint vissza [6], a felsőoktatás egészének nemzetköziesedése viszonylag újabb keletű fejlemény, melyet kvázi válaszreakcióként a felsőoktatás globalizáció által életre hívott tömegesedése váltott ki [7], és a felsőoktatási szolgáltatások, az ebben tevékenykedő munkatársak és hallgatók világszintű versenyét indukálja [4], [8]. Az egyre intenzívebb - hazai és nemzetközi - verseny mellett a csökkenő finanszírozás kettős szorításba helyezi a felsőoktatási intézményeket [9].

Ilyen feltételek mellett nem sokáig volt tartható a hazai felsőoktatási intézmények tradicionális szemlélete, a túlnyomóan „ad hoc” jellegű, tudatos marketingnek alig nevezhető beiskolázási stratégiája, így ezzel felhagyva új alapokra kezdték helyezni az intézmények marketingtevékenységét [5]. A forprofit szférában már bizonyítottan hatékony marketingeszközök alkalmazása azonban csak lassan terjedt el a felsőoktatási szektorban, és még ma sem mondható teljesen általánosnak [10]. Ezzel 
párhuzamosan a kutatók is csak az utóbbi évtizedekben kezdték el vizsgálni a felsőoktatási marketinget [3], [11], így még viszonylag kevés tudományos kutatási eredmény született a témában, különösen kevés hazai forrás áll rendelkezésre.

\subsection{Az imázs szerepe a felsőoktatási marketingben}

A marketing irodalomból régóta ismert, hogy a vállalati imázs kritikus a fogyasztók vásárlási szándékának alakításában [12]. Ennek megfelelően a felsőoktatási intézmények által közvetített imázs is kiemelkedő szerepet játszik az intézmény közönségének intézménnyel kapcsolatos attitűdjének alakításában [13], [14]. A piacvezető szerepet megcélzó felsőoktatási intézményeknek ezért olyan megkülönböztető imázst kell kialakítaniuk és fenntartaniuk, mely versenyelőnyt biztosíthat számukra egy egyre kompetitívebb piacon [15]. Sok esetben nem egyes konkrét adatok, számok, hanem az ezeket is magában foglaló - imázs lesz az, amely alapján a potenciális hallgató jelentkezik az adott intézménybe, a támogató adományozni fog az intézmény számára, illetve a vállalatok hajlandóak lesznek együttműködni az intézménnyel a legkülönfélébb területeken. Kiemelkedően fontos tehát, hogy a növekvő verseny és csökkenő források világában a felsőoktatási intézmények a közönségük elvárásainak megfelelően alakítsák ki, adott esetben módosítsák imázsukat [9], lehetőleg figyelembe véve az eltérő célcsoportok eltérő igényeit, elvárásait, és eszerint differenciálva a közvetített imázst.

Kotler és Fox [16] szerint az imázs a hitek, vélemények és benyomások összessége, melyekkel egy személy rendelkezik az imázs tárgyával kapcsolatban. A legtöbb kutató egyetért abban, hogy az intézményi imázs egy érzékelési folyamat eredményeként jön létre, amely az intézménnyel kapcsolatos gondolatokból, érzésekből és korábbi tapasztalatokból származik, és amelyet a fogyasztó a memóriájából hív elő és mentális képekké alakítja [17]. Általános szabály, hogy amikor a fogyasztó szembesül az intézménnyel kapcsolatos tényekkel, tudatosan vagy tudat alatt csupán azokat őrzi meg a memóriájában, melyek összhangban állnak meglévő attitűdjeivel, hiedelmeivel (avagy a fejében élő imázzsal), így erősítve meg azokat [18].

Természetesen - hasonlóan a vállalati szférához - egy felsőoktatási intézmény imázsa nem abszolút, hanem relatív, a többi intézményhez viszonyítva értelmezhető. Az imázs annak függvénye, hogy az intézmény milyen stratégiákat és hogyan hajt végre, illetve hogyan észleli ezeket a közönség. Az emberek szükségszerűen korlátozott és gyakran - bár nem szükségszerűen - helytelen információkra alapozva alakítják ki a felsőoktatási intézményekre vonatkozó elképzeléseiket, ugyanakkor ez az észlelt imázs nagyban meghatározza, hogy mennyire hajlandóak csatlakozni a szervezethez (hallgatóként vagy munkatársként), adományozni az intézménynek, illetve ajánlani azt másoknak [16]. Az imázs menedzselését az oktatási intézmények széleskörűen használják pozicionálási eszközként azzal a céllal, hogy a hallgatók intézményválasztását befolyásolják [13], [19], [20], sőt, az intézményi imázs hatással lehet a hallgatók adott intézményben való továbbtanulási döntésére (hűségére) is [18], [21]. Ezért fontos, hogy a felsőoktatási intézmények ismerjék a közönségben élő imázsukat, és biztosítsák azt, hogy ez az imázs az intézmény minél pontosabb és kedvező tükörképe [9] (a rövid távú sikert a hosszú táv kárára hajszoló eladók e két szempontból gyakran csak a kedvezőre törekszenek).

Az imázs kialakulásában szerepet játszik a szájreklám, a múltbeli tapasztalatok, illetve az intézmények marketingtevékenysége is [9]. Kutatásunkban mi csupán ez utóbbira koncentrálunk, azaz a 
felsőoktatási intézmények tudatos - bár több esetben laikus, és néhány esetben épp ezért kevéssé hatékony - marketingtevékenysége által közvetített imázst vizsgáljuk, ezen belül is kizárólag az intézményi honlapok néhány aspektusára koncentrálunk.

\subsection{Webmarketing a felsőoktatásban}

A továbbtanulás során a felsőoktatási intézmény kiválasztása magas bevonódással jellemezhető, mivel igen magas a döntés pénzügyi, pszichológiai és társadalmi kockázata. Emellett a felsőoktatás bizalmi jellegű szolgáltatás, hiszen a fogyasztó számára nehéz a szolgáltatás értékelése még az igénybevétel után is [22], [23]. Az ilyen karakterisztikákkal jellemezhető szolgáltatások esetén pedig kiterjedtebb információkeresést feltételezhetünk a vásárlási döntés előtt, és ezen információkeresés elsődleges eszköze az internet [24], mely gyors, kényelmes, gyakorlatilag ingyenes tájékozódást tesz lehetővé. Ezt számos tanulmány megerősítette, például Schimmel et al. [25] kutatásában a megkérdezett hallgatók 94\%-a nyilatkozott úgy, hogy iskolaválasztás előtt megvizsgálja az intézmény honlapját. A kutatás azt is alátámasztotta, hogy az intézményi honlapok használata a döntéshozatali folyamat során jellemzőbb a fiatalabb generációkra, mely trend várhatóan tovább fog folytatódni és még fontosabb faktor lesz, ahogy az új technológiák használata az újabb generációk és a szülőkké váló X és Y generáció tagjai által növekszik.

Számos tanulmány bemutatta már az internet mint marketingeszköz fontosságát a felsőoktatási marketingben. E tanulmányokat három fő kategóriába lehet sorolni [26]: 1) tanulmányok, melyek azt vizsgálják, hogy mit várnak el a hallgatók az intézményi honlapoktól (például [25], [27]), 2) praktikus tanácsok arra vonatkozóan, hogy hogyan lehet az intézményi honlapokat használni arra, hogy minél többen jelentkezzenek az intézménybe (például [25], [28]), 3) a jelenlegi felsőoktatási intézmények honlapjainak elemzése (például [29], [30], [31], [32], [33], [34]). Jelen tanulmány ez utóbbi téren kívánja bővíteni a szakirodalmat, a szerzők tudomása szerint magyar mintán eddig még nem alkalmazott módszertannal.

A felsőoktatási intézmények honlapjai amellett, hogy a kínált szakokat, tematikákat, egyéb elérhetőségeket bemutatják, információt nyújtanak az érdeklődőknek az intézményi hírekről, sőt, a látogatók akár virtuális sétát is tehetnek a campuson. Az információk nyújtása mellett azonban e honlapok egy fontos szerepe, hogy hozzájárulnak az intézmények - külső és belső - közönségben kialakuló és élő imázsához.

Az intézményi honlapok mellett a közösségmédia-oldalak jelentik az egyik példáját a legújabb kommunikációs technológiáknak, amelyeket a hallgatók széles körben használnak, így magas potenciállal rendelkeznek a hallgatók egyetemmel történő kétirányú kommunikációjára [35]. Kutatásunkban nem térünk ki részletesen e felületek imázsformáló szerepére, csupán azt a tényt vizsgáljuk, hogy mely közösségimédia-oldalakon érhetők el a magyar felsőoktatási intézmények a honlapjukon szereplő elérhetőségek alapján, mely önmagában is hozzájárul az intézményi imázshoz. 


\section{Anyag és módszer}

Jelen vizsgálat - a feltáró jelleghez illeszkedve - kvalitatív és kvantitatív módszert is követ, a magyar felsőoktatási intézmények honlapjainak tartalomelemzését foglalja magába, célunk az említett honlapok elsősorban manifeszt, illetve ezen keresztül látens tartalmának feltárása [36]. A tartalomelemzés során az elemzési egységeket az intézmények, a megfigyelési egységeket pedig a honlapokon szereplő elemek (központi helyet elfoglaló képek, az elérhető akadálymentesített felület és nyelvek, valamint a közösségi médiára irányuló linkek) jelentették.

Vizsgálódásaink távlati célja feltárni azt, hogy miként, milyen tényezők alapján határozódik meg a felsőoktatási intézmények által mutatott online imázs. E dolgozat e felé teszi meg az egyik első lépést azzal, hogy olyan magyar felsőoktatási intézménycsoportok között keres különbséget a honlapon közvetített imázsban, amelyekről joggal feltételezhető, hogy eltérő üzenetet kell közvetíteniük. Amennyiben ez a durva struktúra is felmutat jelentős különbségeket, akkor az újabb kutatások már rendelkezni fognak olyan fogódzóval, amelyekre kidolgozottabb hipotézisek építhetőek, és így közelebb kerülhetnek a mélyebb összefüggések felfedezéséhez is. Kutatási kérdéseink tehát:

K1. Van-e különbség a Magyarországon müködő felsőoktatási intézmények honlapjai által közvetített imázsban (az általunk vizsgált, alább részletezett ismérvek szerint) az állami, egyházi és egyéb fenntartású intézmények között?

K2. Van-e eltérés a Magyarországon müködő felsőoktatási intézmények honlapjai által közvetített imázsban (az általunk vizsgált, alább részletezett ismérvek szerint) az egyetemek és föiskolák között? Ezt a kérdést megvizsgáljuk mind az aktuális (K2.1), mind pedig a 2000 elötti (K2.2) besorolás szerint.

Jelen tanulmány nem tudja és nem is kívánja a felsőoktatási intézmények honlapjainak teljes körü elemzését bemutatni, csupán azok nyitólapját vizsgálja, hiszen ez az, amivel minden látogató szükségszerűen találkozik, a nyitólapról viszont csak azok navigálnak tovább a belső tartalmak és így további vizuális elemek felé, akik már érdeklődnek valamilyen okból az intézmény iránt. Ezen belül is az állandó képi elemekre (az úgynevezett „sliderre” és az egyéb állandó képekre), a honlap gyengénlátók számára optimalizált, idegen nyelvű és közösségimédia-elérhetőségére fókuszálunk, mert ezek - mint eredményeinkből is látszani fog - viszonylag elterjedtek, és egyben vizsgálati céljainkat is megfelelően mérik. Az adatok felvételére 2018. február 15-22. között került sor, az intézményi nyitóoldalak felkeresésével és az adatok manuális rögzítésével.

Először az adott oldalon található képek teljes számát rögzítettük ${ }^{1}$, majd ezeket a szerint bontottuk, hogy a slideren vagy azon kívül helyezkednek el. Emellett feljegyeztük azt is, hogy az adott oldal hány és milyen nyelveken érhető el, van-e gyengénlátók számára optimalizált oldala, illetve milyen közösségi médiumokban érhetők el a vizsgált felsőoktatási intézmények a honlapjukon feltüntetett elérhetőségek alapján. Nem vizsgáljuk ugyanakkor a honlapon szereplő képeket témájuk szerint, azt az elemzés méretei és az igényelt eltérő módszertani megközelítés miatt egy későbbi, a jelenlegi dolgozat eredményeire is építő tanulmányban tervezzük kidolgozni.

\footnotetext{
${ }^{1}$ Néhány esetben előfordult, hogy egy kép egy montázs volt, ebben az esetben az egészet egy képként kezeltük.
} 
A vizsgálat idején 65 államilag elismert felsőoktatási intézményt tartott nyilván az Oktatási Hivatal [37], ebből egy nem rendelkezett az adatfelvétel idején honlappal (Szent Bernát Hittudományi Főiskola). Mivel vizsgálati egységeink az intézmények (illetve azok honlapokon keresztül megvalósuló kommunikációs magatartása) voltak, ezért elemzésünk során a honlappal nem bíró intézményre úgy tekintünk, mintha üres honlappal rendelkezne (nincs slidere, nulla képet tartalmaz és így tovább), hiszen ha kimaradna a vizsgálatból, és elemzéseinket csak a 64 elemből álló mintán végeznénk, az torzíthatná az eredményeinket. A 65 intézményből 31 állami, 25 egyházi, 9 pedig egyéb (alapítványi, közalapítványi, közhasznú nonprofit zrt. és kft., valamint kft.) fenntartású volt. Ezek közül 29 volt egyetem, 7 alkalmazott tudományok egyeteme, illetve 29 főiskola. A 65 intézményből 2000 előtt 22 volt egyetem és 43 volt főiskola.

Elemzésünk a kvalitatív és a kvantitatív módszertant egyaránt alkalmazza, ami alatt Babbie [36] után azt értjük, hogy a vizsgált ismérvek alapján minőségi jellemzőket is azonosítunk (slider alkalmazása, közösségimédia-jelenlét feltüntetése...), de az arra lehetőséget biztosító esetekben ezt mennyiségi vizsgálatokkal is kiegészítjük (pl. mely típusú intézmények közölnek jellemzően több képet honlapjaikon).

\section{Eredmények}

\subsection{Sliderek és képek száma}

Első megállapításunk az elemezhető vizuális tartalom tekintetében annak elhelyezésére vonatkozik. A 65 intézményből a túlnyomó többség (51) használt slidert is, és ebből 48-nál (ami a honlappal rendelkező intézmények több mint háromnegyede) más lényeges állandó képi elem nem is volt az oldalon (a hirdetésekhez tartozó, és emiatt a látogató által az intézményhez kevésbé tartozónak érzékelt képi elemeket nem vonjuk be az elemzésbe). A sliderek „hossza” (a benne szereplő képek száma) tág határok közt mozgott: a legrövidebb 2 (Golgota Teológiai Főiskola), a leghosszabb 89 (Állatorvostudományi Egyetem) képből állt. Utóbbi messze kiugró értéknek számít, hiszen az ezt követő leghosszabb slider 10 elemű volt, de két képből álló sliderből sem akadt még egy. Kivételes volt még a Soproni Egyetem honlapja, amelynek két slidere is volt (ezek összesen tartalmazták a megadott képszámot), és a Magyar Táncművészeti Egyetem, amelynek mozgóképekből állt a slidere. A Miskolci Egyetem honlapja pedig abból a szempontból volt kivétel, hogy a vizsgálat idején a slider önmagától nem váltott képet, és nem is szerepelt olyan utalás (pl. számozás, nyíl, vonal, pontok vagy kattintható elemek) a képen, ami jelezte volna, hogy kattintás után újabb képhez juthatunk (vagyis egy passzív szemlélő számára nem működött sliderként, de a kísérletező kedvű látogató „előcsalhatott” újabb képeket a sliderre kattintással). A sliderképek számának megoszlása az összes sliderrel rendelkező honlap mintáján (zárójelben a gyakoriság): 2 (1), 3 (6), 4 (11), 5 (6), 6 (14), 7 (5), 8 (2), 9 (2), 10 (3), 89 (1).

A képek számából levonható tanulság még, hogy az adatok szerint a sliderek háromnegyede 6 vagy annál kevesebb képből állt, a leggyakoribb képszám (módusz) a 6 volt (ez önmagában az esetek több mint egynegyedét tette ki, és egyben ez volt a mediánérték is), a második leggyakoribb pedig a 4 (ez is több mint az esetek egyötöde). Átlagot a normálistól eltérő megoszlás miatt (két módusz, jelentősen 
kiugró érték, jobbra elnyúló eloszlás) nincs értelme meghatározni. Vagyis röviden: a meghatározó mód a képek elhelyezésére a slider volt, és ezek jellemzően 3-7 képből álltak.

\subsection{1. Állami és nem állami intézmények eltérése}

A slideren szereplő képek számában a 27 állami és a 24 nem állami, sliderrel is bíró intézmény közt nem találtunk jelentős eltérést (Mann-Whitney $U=319,500 ; p=0,931$ ). Az állami fenntartású intézmények honlapján a medián képszám 6,000, a nem államiaknál 5,500 volt. A nem állami intézményeken belül a 16 egyházi fenntartású intézmény esetén a medián képszám 5,000 volt, de ez sem különbözött szignifikánsan az állami intézményekétől (Mann-Whitney $U=214,000 ; p=0,959$ ).

Ugyanakkor a fenti intézménykategóriák (28 állami, 37 nem állami, utóbbin belül 25 egyházi) a honlap összes állandó képeinek számában már mutattak eltérést: az állami intézmények honlapjain jelentősen több volt az összes kép, mint az összes nem állami intézményén (Mann-Whitney $U=349,000 ; p=$ $0,024$ ) vagy az összes egyházién (Mann-Whitney $U=229,000 ; p=0,029)$. Az állami intézményeknél a képek medián-száma 6,000, a nem államiaknál 4,000, az egyháziaknál szintén 4,000 volt. A teljes mintában az összes kép (slideren vagy azon kívül elhelyezett) megoszlása (zárójelben a gyakoriságok): 0 (5), 1 (7), 2 (3), 3 (5), 4 (12), 5 (6), 6 (13), 7 (6), 8 (2), 9 (2), 10 (2), 11 (1), 89 (1).

Megállapíthatjuk, hogy a magyar felsőoktatási intézmények honlapjainak nyitóoldalán közölt képek számában csak akkor van eltérés állami és nem állami, illetve állami és egyházi intézmények közt, ha a mintában szerepelnek a slidert nem alkalmazó szervezetek is. Ekkor az állami intézmények jellemzően több képet közölnek. Ha azonban a vizsgálatot csak a slidert is alkalmazókra szúkítjük, a különbség már nem mutatható ki. A szerzők szubjektív magyarázata szerint, mely akár későbbi kutatás témája lehet, a slider egyfajta vízválasztó a tudatos és nem tudatos képi honlaptervezés között. Ebből a szempontból pedig az ezt a küszöböt meglépő szervezetek nem térnek el fenntartójuk szerint. Ugyanakkor maga a tudatosság elterjedtebb az állami intézmények körében.

Ezt a megállapítást a slider létének (van vagy nincs) vizsgálata is alátámasztja. A 28 állami intézményből mindössze 1 nem rendelkezett sliderrel (Nyíregyházi Egyetem), az összes nem államiak (37) közül 13, az egyháziak (25) közül pedig 9. Mind az állami vs. nem állami $\left(\chi^{2}=9,393 ; p=0,002\right)$, mind az állami vs. egyházi összehasonlítás khí-négyzet próbája szignifikáns különbséget mutatott $\chi^{2}=$ 9,073; $p=0,003$ ). A nem állami és nem is egyházi fenntartású intézmények száma túl alacsony volt a statisztikai vizsgálathoz.

\subsubsection{Egyetemek és föiskolák eltérése}

Mivel Magyarországon az utóbbi két évtizedben fokozatosan egyetemmé, illetve alkalmazott tudományok egyetemévé minősítettek át több főiskolát (jelen cikk írásakor mindössze egyetlen állami főiskola létezik, a bajai Eötvös József Főiskola), ám ez a változás a legtöbb esetben külső, jogszabályi, és nem belső, intézményi okokból történt, ezért szükségesnek tartottuk a 2000 előtti besorolás szerint is összehasonlítani az egyetemeket és főiskolákat. Ennek eredményeit közöljük először. Bár komoly intézményi változások is történtek időközben (pl. összevonások), ezek elemzésbe való beemelésétől eltekintünk. 
2000 előtt a mintánk 43 eleme volt főiskola, 22 pedig egyetem. Az előbbiek közül 30, utóbbiak közül 21 honlapja rendelkezett a vizsgált időszakban sliderrel, a különbség szignifikáns $\left(\chi^{2}=5,682 ; p=\right.$ 0,017). Vagyis a 3.1.1. alfejezetben említett képi tudatosság nem csak az állami, de az egyetemi múlttal rendelkező intézmények esetében is gyakoribb volt, mint egyéb versenytársaiknál.

Az összes honlapon közölt kép esetében kevesebb mint 1\%-os szinten szignifikáns különbséget találtunk a két csoport között az egyetemek javára (Mann-Whitney $U=255,000 ; p=0,002$ ). A főiskolai múlttal rendelkező intézmények által közölt képek számának mediánja 4,000, az egyetemi múlttal rendelkezőké 6,000 volt.

Ha csak a sliderrel is rendelkező honlapokat vesszük figyelembe, az egyetemi múlttal rendelkezők akkor is több képet közöltek sliderenként (medián képszám egyetemi múlttal: 6,000, főiskolaival: 5,000), a különbség azonban csak 10\%-on szignifikáns (Mann-Whitney $U=222,000 ; p=0,070$ ).

Ha a jelenlegi tipológiát tesszük elemzésünk alapjává (a mintában 29 egyetem, 7 alkalmazott tudományok egyeteme és 29 főiskola szerepel), akkor mivel az alkalmazott tudományok egyetemeinek alacsony száma miatt azok külön csoportként való statisztikai elemzése nem indokolt, ezért kénytelenek voltunk kihagyni azokat a vizsgálatból (nem vonhattuk őket össze sem az egyetemekkel, sem a főiskolákkal, hiszen éppen a jelenlegi besorolás szerint akartuk elvégezni az elemzést). A teljesség kedvéért a slider alkalmazásának gyakoriságait és a képszámok mediánjait ugyanakkor mindhárom kategóriára közöljük az 1. táblázatban, az elvégzett próbák statisztikái mellett (amelyek azonban minden esetben csak a főiskolák és egyetemek csoportjait hasonlítják össze).

\begin{tabular}{|l|c|c|c|c|}
\hline Jelenlegi rang & $\mathrm{N}$ & Van slider & $\begin{array}{c}\text { Medián } \\
\text { összképszám }\end{array}$ & $\begin{array}{c}\text { Medián } \\
\text { sliderképszám }\end{array}$ \\
\hline egyetem & 29 & 27 & 6,000 & 6,000 \\
\hline $\begin{array}{l}\text { alkalmazott tud. } \\
\text { egyeteme }\end{array}$ & 7 & 6 & 4,000 & 4,500 \\
\hline főiskola & 29 & 18 & 4,000 & 5,000 \\
\hline $\begin{array}{l}\text { egyetemek vs. } \\
\text { főiskolák }\end{array}$ & Próbastatisztika & $\begin{array}{c}\chi^{2}=8,031 \\
p=0,005\end{array}$ & $\begin{array}{c}U=255,000 \\
p=0,009\end{array}$ & $\begin{array}{c}U=208,500 \\
p=0,415\end{array}$ \\
\hline
\end{tabular}

1. táblázat: Slider alkalmazása és a közölt képek száma intézménytípusonként (db).

Az 1. táblázatban közölt eredmények a slider létére és az összes képszámra vonatkozóan megerősítik a 2000 előtti besorolás vizsgálatakor kapott eredményeket: az egyetemek a jelenlegi besorolás szerint is hajlamosabbak slidert alkalmazni és összesen több képet közölni, mint a főiskolák. A sliderek hossza azonban már nem tér el jelentősen a slidert használó egyetemek és főiskolák összehasonlításakor. Összefoglalóan: ha egy intézmény egyetemi ranggal rendelkezik, illetve rendelkezett 2000 előtt is, akkor nagyobb eséllyel használ slidert és közöl több képet a honlapján, mint a jelenleg, illetve 2000 előtt főiskolai ranggal bírók. A sliderek viszont csak a 2000 előtti kategóriák alapján vizsgálva tartalmaztak jelentősen több képet az egyetemek esetében, mint főiskoláknál. Úgy tűnik tehát, hogy $a z$ egyetemi rang együtt jár a tudatosabb és aktívabb képközléssel az intézmények fóoldalán, kivéve a 
sliderek képeinek számát, ahol ez a különbség az aktuális állapot szerint már nem kimutatható, csak a 2000 elótti besorolást alkalmazva.

\subsection{Elérhetőség vakok, gyengénlátók és magyar nyelven nem értők számára}

A 2. táblázat fenntartó, illetve rang (egyetem, alkalmazott tudományok egyeteme, fóiskola) szerint tartalmazza annak gyakoriságait, hogy elérhető-e az adott intézmény főoldala vakok és gyengénlátók számára (akadálymentes), illetve idegen nyelveken.

\subsubsection{Eltérések az akadálymentes verzió elérhetöségében}

Az állami és nem állami intézmények $\left(\chi^{2}=20,365 ; p<0,001\right)$, illetve az állami és az egyházi intézmények $\left(\chi^{2}=20,872 ; p<0,001\right)$ egy ezrelékes szignifikancia-szinten különböznek egymástól abban a tekintetben, hogy elérhető-e honlapjuk főoldala akadálymentes verzióban is. Mindkét összehasonlításban az állami intézmények esetében sokkal gyakoribb az ilyen szolgáltatás.

Arányaiban szignifikánsan több akadálymentes honlappal bírnak a 2000 előtt is egyetemi ranggal rendelkező intézmények, mint amelyek akkor még/is főiskolaként voltak besorolva $\left(\chi^{2}=3,876 ; p=\right.$ 0,049). A jelenlegi besorolás alapján a statisztikai vizsgálat csak a főiskolák és egyetemek közötti eltérésre végezhető el (a harmadik kategória alacsony elemszáma miatt). Ekkor is azt tapasztaljuk, de jóval erősebb megbízhatóság mellett, hogy az egyetemek hajlamosabbak akadálymentes verziót is készíteni honlapjukról $\left(\chi^{2}=12,429 ; p<0,001\right)$.

Összességében tehát az állami intézmények és az egyetemek, illetve a hosszabb egyetemi múlttal rendelkezố szervezetek rendelkeztek inkább akadálymentes verzióval, mint a nem állami fenntartásúak vagy a jelenlegi és 2000 előtti föiskolák.

\begin{tabular}{|c|c|c|c|c|c|c|c|c|c|}
\hline \multirow[t]{2}{*}{ Tipológia } & \multirow[t]{2}{*}{ Besorolás } & \multirow{2}{*}{$\begin{array}{l}\text { Akadály- } \\
\text { mentes }\end{array}$} & \multicolumn{7}{|c|}{ Elérhető nyelvek } \\
\hline & & & angol & német & spanyol & kínai & orosz & japán & koreai \\
\hline \multirow{3}{*}{ fenntartó } & állam & 18 & 29 & 4 & 1 & 2 & 0 & 1 & 1 \\
\hline & egyéb & 4 & 12 & 1 & 1 & 0 & 0 & 0 & 0 \\
\hline & $\begin{array}{l}\text { ebből } \\
\text { egyház }\end{array}$ & 1 & 8 & 1 & 0 & 0 & 1 & 0 & 0 \\
\hline \multirow{2}{*}{$\begin{array}{l}\text { rang } \\
2000-i g\end{array}$} & egyetem & 11 & 20 & 5 & 0 & 1 & 0 & 0 & 0 \\
\hline & főiskola & 11 & 29 & 1 & 2 & 1 & 1 & 1 & 1 \\
\hline \multirow{3}{*}{$\begin{array}{l}\text { jelenlegi } \\
\text { rang }\end{array}$} & egyetem & 14 & 27 & 5 & 1 & 2 & 0 & 1 & 1 \\
\hline & $\begin{array}{l}\text { alk. tud. } \\
\text { egyeteme }\end{array}$ & 6 & 7 & 0 & 0 & 0 & 0 & 0 & 0 \\
\hline & főiskola & 2 & 15 & 1 & 1 & 0 & 1 & 0 & 0 \\
\hline \multicolumn{2}{|l|}{ Összesen } & 22 & 49 & 6 & 2 & 2 & 1 & 1 & 1 \\
\hline
\end{tabular}

2. táblázat: A felsőoktatási intézmények honlapjainak elérhetôsége vakok, gyengénlátók számára és idegen nyelveken. 


\subsubsection{Eltérések az idegen nyelvü verziók elérhetöségében}

A többnyelvű elérhetőség esetében az első megállapítás, hogy ahol nincs angol verzió, ott más nyelvű verzió sem elérhető (a magyaron kívül). Vagyis az angol nyelvü elérhetőség minden esetben alapvetőnek, „első lépésnek” számít. Az állami intézmények esetében jelentősen gyakoribb volt a legalább angol nyelvű elérhetőség biztosítása, mint a nem állami $\left(\chi^{2}=8,093 ; p=0,004\right)$, vagy mint az egyházi fenntartású $\left(\chi^{2}=13,097 ; p<0,001\right)$ intézmények esetében.

$\mathrm{Az}$ összes elérhető idegen nyelvre vonatkozó vizsgálat hasonló eredményt hozott. Az állami intézmények oldalai jelentősen több nyelven érhetőek el (medián $=1,000$ ), mint a nem államiak (medián $=1,000$; Mann-Whitney $U=329,000 ; p=0,004$ ), vagy ezen belül az egyháziak (medián = 0,000; Mann-Whitney $U=170,000 ; p<0,001$ ).

A 2000 előtti egyetemek is inkább rendelkeztek legalább angol verzióval, mint a 2000 előtti főiskolák $\left(\chi^{2}=4,319 ; p=0,038\right)$, de a jelenlegi besorolás szerinti egyetemek és főiskolák viszonyában is hasonló a helyzet, még alacsonyabb szignifikancia-szint mellett $\left(\chi^{2}=12,429 ; p<0,001\right)$.

Az összes elérhető idegen nyelvek számában is jobban szerepeltek a 2000 előtt is egyetemi rangban lévő intézmények (medián = 1,000), mint a 2000 előtt főiskolaként működők (medián = 1,000; MannWhitney $U=305,000 ; p=0,007$ ), illetve a jelenlegi egyetemek (medián $=1,000$ ) is felülmúlják ezen a téren a jelenlegi főiskolákat (medián $=1,000$; Mann-Whitney $U=221,000 ; p<0,001$ ), habár a mediánértékek megegyeznek (a különbség nem nagy, de statisztikailag jelentős)

A legalább angol, illetve a több nyelven való elérhetőség, csakúgy, mint a korábban vizsgált akadálymentes verzió jelenléte, jellemzőbb volt az állami intézményekre és az egyetemekre (mind a jelenlegi, mind a korábbi besorolás szerint), mint a nem állami intézményekre és a főiskolákra.

\subsection{Közösségi média elérhetősége}

Az egyes közösségi oldalak nyitólapon történő összes megjelöléseit a 3. táblázat mutatja, fenntartó és rang szerinti bontásban (2000 előtti és jelenlegi állás szerint is). A főoldalon megjelölt közösségimédia-elérhetőségek közt ugyanolyan küszöb-szerepet töltött be a Facebook, mint a nyelvek között az angol: ha egy oldalon nem volt megjelölve Facebook-elérhetöség, akkor nem volt más elérhetöség sem. 


\begin{tabular}{|c|c|c|c|c|c|c|c|c|c|c|c|}
\hline \multirow[t]{2}{*}{ Tipológia } & \multirow[t]{2}{*}{ Besorolás } & \multicolumn{10}{|c|}{ Elérhető közösségi oldalak } \\
\hline & & 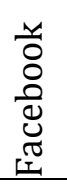 & 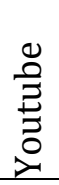 & 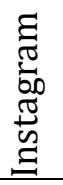 & 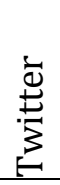 & 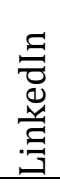 & $\begin{array}{l}+ \\
\frac{0}{00} \\
80 \\
0 \\
0\end{array}$ & $\frac{\dot{y}}{0}$ & $\stackrel{\Xi}{\Xi}$ & 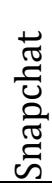 & 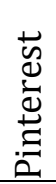 \\
\hline \multirow{3}{*}{ fenntartó } & állam & 25 & 14 & 12 & 8 & 7 & 4 & 2 & 1 & 0 & 0 \\
\hline & egyéb & 14 & 7 & 2 & 3 & 1 & 1 & 0 & 0 & 0 & 0 \\
\hline & $\begin{array}{l}\text { ebből } \\
\text { egyház }\end{array}$ & 7 & 4 & 3 & 3 & 2 & 3 & 0 & 0 & 1 & 1 \\
\hline \multirow{2}{*}{$\begin{array}{l}\text { rang } \\
2000-i g\end{array}$} & egyetem & 19 & 11 & 10 & 8 & 8 & 4 & 2 & 1 & 0 & 0 \\
\hline & főiskola & 28 & 15 & 8 & 8 & 2 & 5 & 0 & 0 & 1 & 1 \\
\hline \multirow{3}{*}{$\begin{array}{l}\text { jelenlegi } \\
\text { rang }\end{array}$} & egyetem & 23 & 12 & 11 & 10 & 8 & 5 & 2 & 1 & 0 & 0 \\
\hline & $\begin{array}{l}\text { alk. tud. } \\
\text { egyeteme }\end{array}$ & 7 & 4 & 4 & 1 & 1 & 0 & 0 & 0 & 0 & 0 \\
\hline & föiskola & 17 & 10 & 3 & 4 & 1 & 3 & 0 & 0 & 1 & 1 \\
\hline \multicolumn{2}{|l|}{ Összesen } & 46 & 25 & 17 & 14 & 10 & 8 & 2 & 1 & 1 & 1 \\
\hline
\end{tabular}

3. táblázat: A felsőoktatási intézmények közösségimédia-elérhetőségének megjelenése honlapjuk nyitóoldalán.

Az egyes vizsgálati szempontokra (fenntartó, rang) elvégzett statisztikai próbák adatait a 4. táblázat foglalja össze. Csak azokat a közösségi médiumokat tartalmazza a táblázat, melyeknél a jelölések száma elegendő volt a statisztikai vizsgálatok elvégzéséhez.

A 4. táblázatban közölt eredményeket úgy foglalhatjuk össze, hogy a közösségi médiában való megjelenés feltüntetése mind a tulajdonossal (állami, nem állami, egyházi), mind az intézmény rangjával (egyetem, főiskola) összefüggést mutatott.

Az állami intézmények mind a nem államiakhoz, mind ezen belül az egyháziakhoz képest szignifikánsan hajlamosabbak voltak legalább egy közösségimédia-elérés feltüntetésére, konkrétan pedig a Facebook és az Instagram megjelölésére, illetve a feltüntetett ilyen elérhetőségek várható száma is jelentősen nagyobb volt állami fenntartás esetén. 10\%-os szignifikancia-szinten pedig a Twitter-jelenlét megjelölésére tűntek kevésbé hajlamosnak az egyházi fenntartásúak az állami szervezeteknél. 


\begin{tabular}{|c|c|c|c|c|c|}
\hline & \multicolumn{4}{|c|}{ Összehasonlítás } \\
\hline & & $\begin{array}{l}\text { állami vs. } \\
\text { egyéb }\end{array}$ & $\begin{array}{l}\text { állami vs. } \\
\text { egyházi }\end{array}$ & $\begin{array}{c}2000 \text { előtti } \\
\text { egyetem vs. } \\
2000 \text { előtti } \\
\text { főiskola }\end{array}$ & $\begin{array}{l}\text { egyetem vs. } \\
\text { főiskola }\end{array}$ \\
\hline \multicolumn{2}{|l|}{ Facebook } & $\begin{array}{l}\chi^{2}=4,415 \\
p=0,036\end{array}$ & $\begin{array}{l}\chi^{2}=5,747 \\
p=0,017\end{array}$ & $\begin{array}{l}\chi^{2}=3,281 \\
p=0,070\end{array}$ & $\begin{array}{l}\chi^{2}=2,900 \\
p=0,089\end{array}$ \\
\hline \multicolumn{2}{|l|}{ Youtube } & $\begin{array}{l}\chi^{2}=2,050 \\
p=0,152\end{array}$ & $\begin{array}{l}\chi^{2}=2,672 \\
p=0,102\end{array}$ & $\begin{array}{l}\chi^{2}=1,363 \\
p=0,239\end{array}$ & $\begin{array}{l}\chi^{2}=0,293 \\
p=0,588\end{array}$ \\
\hline \multicolumn{2}{|l|}{ Instagram } & $\begin{array}{l}\chi^{2}=5,649 \\
p=0,017\end{array}$ & $\begin{array}{l}\chi^{2}=8,256 \\
p=0,004\end{array}$ & $\begin{array}{l}\chi^{2}=5,240 \\
p=0,022\end{array}$ & $\begin{array}{l}\chi^{2}=6,026 \\
p=0,014\end{array}$ \\
\hline \multicolumn{2}{|l|}{ Twitter } & $\begin{array}{l}\chi^{2}=2,278 \\
p=0,131\end{array}$ & $\begin{array}{l}\chi^{2}=3,060 \\
p=0,080\end{array}$ & $\begin{array}{l}\chi^{2}=3,307 \\
p=0,069\end{array}$ & $\begin{array}{l}\chi^{2}=3,390 \\
p=0,066\end{array}$ \\
\hline \multirow{2}{*}{$\begin{array}{l}\text { Összes } \\
\text { közösségi } \\
\text { média }\end{array}$} & medián & $\begin{array}{l}\text { állami: } 2,000 \\
\text { egyéb: } 1,000\end{array}$ & $\begin{array}{l}\text { állami: } 2,000 \\
\text { egyházi: } 1,000\end{array}$ & $\begin{array}{l}\text { egyetem: } 2,500 \\
\text { főiskola: } 1,000\end{array}$ & $\begin{array}{l}\text { egyetem: } 2,000 \\
\text { föiskola: } 1,000\end{array}$ \\
\hline & $\begin{array}{l}\text { Próbastat. } \\
\text { Szign.-szint }\end{array}$ & $\begin{array}{l}U=331,500 \\
p=0,012\end{array}$ & $\begin{array}{l}U=184,500 \\
p=0,003\end{array}$ & $\begin{array}{l}U=289,000 \\
p=0,013\end{array}$ & $\begin{array}{l}U=287,000 \\
p=0,034\end{array}$ \\
\hline
\end{tabular}

4. táblázat: Különbségek a felsőoktatási intézmények honlapjainak nyitóoldalán feltüntetett közösségimédiaelérhetőségben.

Az egyetemi múltú intézmények 10\%-os szignifikancia-szinten hajlamosabbnak mutatkoztak valamilyen közösségi média, illetve ezen belül a Facebok és a Twitter feltüntetésére, mint a főiskolai múltúak, 5\%-on pedig gyakoribb volt az előbbiek esetén az Instagram megjelölése. Szignifikánsan több volt továbbá az összes közösségimédia-feltüntetés az egyetemi, mint a főiskolai múlt esetében. A jelenlegi egyetemek és fóiskolák közti különbségekre éppen azok a tapasztalatok igazak, mint a 2000 előtti intézményi besorolások összehasonlítására.

Összefoglalva tehát az állami fenntartás és az egyetemi rang is valószínüsíti az aktívabb közösségimédiajelenlétet, mind a legalább egy médium használatát, mind az összes használt médium számát illetően. Érdekesség továbbá, hogy az Instagram-jelenlét minden vizsgált párosítás esetében differenciálódott, míg a Youtube-jelenlét egyik esetben sem.

\section{4. Összefoglalás és következtetések}

Tanulmányunk a Magyarországon működő felsőoktatási intézmények által, honlapjukon keresztül kommunikált imázs elemzésében kívánt úttörő szerepet betölteni. Ehhez a hazai intézmények alapvető csoportjai (egyetemek vs. főiskolák; állami vs. nem állami; állami vs. egyházi) közti különbségekre koncentrált. Az általunk azonosított különbségek alapján a későbbiekben részletesebb hipotézisek dolgozhatóak ki, és az alapvető tényezők (mi okozza az adott csoportok közti különbségeket) is vizsgálhatókká válhatnak. Mivel feltáró, tapogatózó jellegű lehetett csak az elemzés, ezért kevés, de jól megragadható, egyértelműen azonosítható ismérvvel dolgoztunk. Ezekben közös volt, hogy mind a nyitottság valamilyen dimenziójához kapcsolódott. A képi elemek száma például a megosztani kívánt információ mennyiségére utal, az akadálymentesített és a több nyelven elérhető honlap a szélesebb 
közönség megcélzására, a közösségi oldalak pedig bővítik azon csatornák számát, amin keresztül elérhető az intézményről rendelkezésre álló információ. Mivel tájékozódó jellegű volt a kutatás, nem indultunk el a mélyebb tartalmak felé, kizárólag a főoldal alapján végeztük az elemzést (amit az is indokolt, hogy ez a legkönnyebben, legszélesebb közönség számára elérhető felület). Az alábbiakban a főbb megállapításainkat összegezzük.

Dolgozatunk eredményei alapján levonhatjuk azt a tanulságot, hogy a honlapok közvetíthetnek valamely intézménycsoportra jellemző imázst. Vannak ugyanis olyan jelzések (ezek közül mi csak néhányat vizsgáltunk, de lehet több ilyen is), amelyek differenciálnak állami és nem állami intézmények, egyetemek és főiskolák között. Ha valamely intézmény menedzsmentje szeretné a honlapján keresztül is kifejezni, hogy szervezete melyik csoporthoz tartozik vagy melyikhez kíván hasonlítani, akkor ezekre a jelzésekre érdemes figyelnie. Tipikusan hasznos lehet e jelzések azonosítása például a frissen egyetemmé vált főiskolák számára, vagy azok számára, amelyek azzá terveznek válni, hiszen a kutatásunk arra is rámutatott, hogy e jelzések mentén csak ritkán volt különbség a 2000 előtti vagy a jelenlegi kategóriák szerint elvégzett elemzés eredményeiben. Vagyis az egyetemi státusz megszerzését csoportszinten nem követte az ezzel járó arculatelemek felvétele, legalábbis az általunk vizsgált ismérvek mentén. Ez marketing szempontból azt is jelenti, hogy az éppen tájékozódó leendő hallgató is különbséget fog érzékelni az „igazi” („régi”) és az „új” egyetemek között, ami sok esetben bizonyára nem kívánatos az „újak” számára.

A jelenlegi vizsgálat által azonosított, differenciálásra alkalmas, imázst befolyásoló jelzések alapján elmondható, hogy Magyarországon a vizsgálat idején az állami vagy egyetemi státuszú intézmények a nem ilyen besorolásúakhoz képest:

- összességében több képet közöltek honlapjaikon (slideren és azon kívül együttesen);

- gyakrabban alkalmaztak slidert (ha azonban alkalmaztak slidert, akkor már nem jelezte a csoporthoz tartozást, hogy azon több vagy kevesebb kép váltotta egymást, csak a 2000 előtti besorolás szerinti egyetem-főiskola párosításban);

- inkább rendelkeztek akadálymentes verzióval vakok és gyengénlátók számára;

- többször biztosítottak legalább angol nyelvű elérhetőséget és összességében is több nyelven voltak elérhetőek;

- hajlamosabbak voltak legalább Facebook-elérhetőséget jelezni honlapjuk főoldalán és összességében is több közösségi médiumban mutatták magukat ott elérhetőnek;

- utóbbiak közül tipikusan hajlamosabbak voltak jelen lenni az Instagramon (ez volt a leginkább differenciáló platform), de gyengébb szignifikancia mellett a Facebook- és a Twitter-jelenlét is differenciált, a Youtube-jelenlét viszont nem;

- általában véve nyitottabbak, több információt közöltek.

Érdekességként, a fô kérdéseinkhez nem kapcsolódva kimutattuk továbbá, hogy:

- a képek elhelyezésére a slider volt a meghatározó technika;

- a sliderek legtöbbje 3-7 képből állt;

- a 65-ből 49 intézménynek volt angolul is elérhető honlapja, ezek közül 6 német verzióval is bírt, de egyetlen másik nyelv sem volt jelen kettőnél több honlapon; 
- csak a Facebook, a Youtube, az Instagram, a Twitter és a LinkedIn volt jelen a minta legalább 10 intézményénél;

- a közösségi média esetében a Facebook-, az idegen nyelvek esetében az angol elérhetőség jelenléte „küszöbként” funkcionált: ha ezek nem voltak jelen, akkor egyéb közösségimédia-, illetve idegen nyelvű elérhetőség sem volt a honlapon;

- a főiskolából 2000 után egyetemmé vált intézmények honlap-megjelenése a vizsgált paraméterekben továbbra is elkülönül a régebbi múltú egyetemekétől.

A kutatás korlátját jelenti, hogy - bár az összes Magyarországon államilag elismert felsőoktatási intézményre kiterjed -, csupán egy marketingkommunikációs csatorna (a honlap) és annak is csak a nyitóoldalon megjelenő néhány eleme által közvetített imázsra vonatkozik. A későbbiekben érdemes lenne a kutatást kiterjeszteni a nyitólapon vizsgált honlapelemeken kívüliekre is, a honlapok aloldalaira, illetve egyéb marketingkommunikációs (akár online, akár offline) csatornákra is. Nyilvánvaló továbbviteli lehetőség a vizsgált honlapelemek mélységi elemzése: a képek tartalma, az idegen nyelvű oldalak kidolgozottsága, a közösségi média által ténylegesen közölt tartalom csak néhány a legfontosabb lehetőségek közül. További kutatási irány lehet a hazai tapasztalatok összevetése a külföldi intézmények által közvetített imázzsal.

\section{Hivatkozások}

[1] S. S. Bagley - L. M. Portnoi (2014) Setting the Stage: Global Competition in Higher Education. In: S. S. Bagley - L. M. Portnoi (szerk.): New Directions for Higher Education, Jossey-Bass, San Francisco. pp. 5-11.

[2] A. L. Popa (2015) Understanding Students' Needs For A More Effective Online Marketing In The Higher Education System. Annals of the University of Oradea - Economic Science Series, 24 (1) pp. 1278-1284.

[3] J. Hemsley-Brown - I. Oplatka (2006) Universities in a competitive global marketplace: A systematic review of the literature on higher education marketing. International Journal of Public Sector Management, 19 (4) pp. 316-338.

[4] B. Lepori - M. Seeber - A. Bonaccorsi (2015) Competition for talent. Country and organizational-level effects in the internationalization of European higher education institutions. Research Policy, 44 (3) pp. 789-802.

[5] L. Komáromi - J. Lehota (2002) Marketing és felsőoktatás. In: Á. Garamhegyi - É. Árpádfalviné Szabó (szerk.): Az információs társadalom marketing kihívásai, Szegedi Tudományegyetem Gazdaságtudományi Kar, Szeged. pp. 28-36.

[6] Á. R. Deákné Dusa (2017) Nemzetköziesedés a Debreceni Egyetemen - A hallgatói mobilitás mint a nemzetköziesedés célja és eszköze. Egyetemi doktori (PhD-) értekezés. Debreceni Egyetem Humán Tudományok Doktori Iskolája, Debrecen.

[7] E. Tóth - M. Kiss (2017) A külföldi hallgatók elégedettségi felmérése a Debreceni Egyetem Gazdaságtudományi Karán. Debreceni Szemle, 25 (4) pp. 499-511.

[8] P. G. Altbach (2002) Perspectives on International Higher Education. Change: The Magazine of Higher Learning, May/June, pp. 29-31.

[9] J. Ivy (2001) Higher education institution image: a correspondence analysis approach. The International Journal of Education Marketing, 15 (6) pp. 276-282. 
[10] I. Piskóti (2011) Módszertani és szervezeti megoldások az egyetemi marketingben. Felsőoktatási Mühely, 5 (2) pp. 39-51.

[11] G. Kuráth - M. Törőcsik (2011) Felsőoktatási marketing kihívások. Felsőoktatási Műhely, 3 (2) pp. 15-23.

[12] H. Barich - P. Kotler (1991) A framework for marketing image management. Sloan Managemenet Review, 32 (2) pp. 94-104.

[13] S. Wilkins - J. Huisman (2015) Factors affecting university image formation among prospective higher education students: the case of international branch campuses. Studies in Higher Education, 40 (7) pp. 1256-1272.

[14] U. Yavas - D. J. Shemwell (1996) Graphical representation of university image: a correspondence analysis. Journal of Marketing for Higher Education, 7 (2) pp. 75-84.

[15] R. Paramewaran - A. E. Glowacka (1995) University image: an information processing perspective. Journal of Marketing for Higher Education, 6 (2) pp. 41-56.

[16] P. Kotler - K. Fox (1995) Strategic Marketing for Educational Institutions. 2nd ed., Prentice-Hall, Englewood Cliffs, NJ.

[17] J. C. Yuille - M. J. Catchpole (1977) The role of imagery in models of cognition. Journal of Mental Imagery, 1 (1) pp. 171-180.

[18] N. Nguyen - G. LeBlanc (2001) Image and reputation of higher education institutions in students' retention decisions. The International Journal of Educational Management, 15 (6) pp. 303-311.

[19] K. Milo - K. C. Edson - V. McEuen (1989) The impact of negative publicity on institutional reputation and student college choice. College and University, 64 (3) pp. 237-245.

[20] J. Weissman (1990) Institutional image assessment and modification in college and universities. Journal of Higher Education Management, 6 (1) pp. 65-75.

[21] R. M. Brown - T. W. Mazzarol (2009) The importance of institutional image to student satisfaction and loyalty within higher education. Higher Education, 58 (1) pp. 81-95.

[22] H. Pham - S. L. Lai (2016) Higher Education as an Extended Duration Service: An Investigation of the Determinants of Vietnamese Overseas Student Loyalty. Journal of Studies in International Education, 20 (5) pp. 454-471.

[23] V. A. Zeithaml (1981) How consumer evaluation processes differ between goods and services. In: J. H. Donnelly - W. R. George (szerk.): Marketing of Services, Chicago American Marketing Association, pp. 186-189.

[24] B. Benjamin - J. Lee (2005) Enhancing Your Web Site as a Recruitment Tool by Implementing Chat Technology. In: Proceedings of the 2005 ASCUE Conference, Association of Small Computer Users in Education (ASCUE), pp. 31-39.

[25] K. Schimmel - D. Motley - S. Racic - G. Marco - M. Eschenfelder (2010) The importance of university web pages in selecting a higher education institution. Research in Higher Education Journal, 9 pp. 1-16.

[26] M. Klassen (2002) Relationship marketing on the Internet: the case of top-and lower-ranked US universities and colleges. Journal of Retailing and Consumer Services, 9 (2) pp. 81-85.

[27] O. McKnight - R. Paugh (1999) Floating a university Web sites: If you're going to fish, bring the right bait. In: Proceedings of the 1999 Symposium for the Marketing of Higher Education, American Marketing Association, Chicago. pp. 156-162. 
[28] M. C. Poock - D. Lefond (2001) How College-Bound Prospects Perceive University Web Sites: Findings, Implications, and Turning Browsers into Applicants. College and University, 77 (1) pp. $15-21$.

[29] J. Gordon - S. Berhow (2009) University websites and dialogic features for building relationships with potential students. Public Relations Review, 35 (2) pp. 150-152.

[30] B. Kittle - D. Ciba (2001) Using college web sites for student recruitment: A relationship marketing study. Journal of Marketing for Higher Education, 11 (3) pp. 17-37.

[31] M. Klassen - E. Sitzman (2000) At the intersection of demand creation, demand fulfillment: which schools are getting there first and why? Journal of Marketing for Higher Education, 10 (1) pp. 43-53.

[32] J. Lee - M. You (2011) Marketing Management on Collegiate Website: A Comparison of USA and Taiwan University Admissions Web-pages, e-CASE \& e-Tech Conference Proceeding, The organization of e-CASE \& e-Tech, http://192.192.83.167/ir/bitstream/987654321/1219/ 2/434.pdf, letöltés ideje: 2018. február 15.

[33] T. C. Ooi - H. W. Leong Ho - S. Amri (2010) Education websites and their benefits to potential international students: a case study of higher education service providers in Malaysia. Current Issues in Education, 13 (1) pp. 1-36.

[34] T. Zhang (2017) The Marketization of Higher Education Discourse: A Genre Analysis of University Website Homepages in China. Higher Education Studies, 7 (3) pp. 64-79.

[35] M. D. Roblyer - M. McDaniel - M. Webb - J. Herman - J. V. Witty (2010) Findings on Facebook in higher education: A comparison of college faculty and student uses and perceptions of social networking sites. Internet and Higher Education, 13 (3) pp. 134-140.

[36] E. Babbie (2013) The Practice of Social Research, Wadsworth, Cengage Learning, Belmont, CA.

[37] OH (2017) Államilag elismert felsőoktatási intézmények. Oktatási Hivatal honlapja: https://www.oktatas.hu/felsooktatas/kozerdeku_adatok/felsooktatasi_adatok_kozzetetele/fel sooktatasi_intezmenyek/allamilag_elismert_felsookt_int, letöltés ideje: 2018. február 15. 